\title{
NON-CLOTTING HAEMOLYMPH OF WSSV-INFECTED SHRIMP: IS IT A FACTOR IN INFECTION PROCESSES?
}

\author{
Coco Kokarkin S. \#
}

\begin{abstract}
White spot syndrome virus is recognized as the most prominent pathogen of penaeid shrimp and has been affecting this shrimp farming industry around the world. The virus may reduce the shrimp's immune response and alter enzymatic and biochemical composition of tissues. Similar to other environmental stressed or other pathogeninfected shrimp, in late stages of WSSV infection, shrimp will fail to clot the haemolymph, so any minor injury will lead to increased haemolyph loss. A series of experiments to determine the effect of non-clotting haemolymph on WSSV infection were carried out in controlled facilities in Indonesia. The preliminary test showed that normal clotting time was 13.3 seconds while WSSV-injected shrimp mostly failed to clot their haemolymph 16 hours post infection (hpi). Some other clinical signs such as abnormal swimming, red discoloration, white spots and mortality were consistent with those observed by previous studies. Three shrimp species: banana shrimp (P. merguiensis) $9 \mathrm{~g}$, white leg shrimp (P. vannamei) $7 \mathrm{~g}$ and the tiger shrimp (P. monodon) $16.5 \mathrm{~g}$ were water-borne-challenged with non-clotting, WSSV-infected haemolymph $(\mathrm{NCH})$ from tiger shrimp donor in duplicate tanks each with 12 shrimp. The control were tiger shrimps fed with WSSV-infected tissue at the rate of $40 \%$ of bodyweight (BW) and other tiger shrimps were used as negative controls fed with commercial feed only. The study revealed that $\mathrm{NCH}$ dosages of $1.46 \% ; 2.03 \%$; and $2.06 \%(\mathrm{v} / \mathrm{v})$ for each species were sufficient to infect and kill all shrimps in less than two days compared to eight days for the shrimps fed on infected tissue. The WSSV in non-clotted haemolymph eventuallyattaches into the living tissues of healthy shrimp. This mode of infection is likely more difficult to control by the ordinary fine mesh screening method.
\end{abstract}

KEYWORDS: non-clotting-haemolymph, WSSV, infectious, Penaeus monodon, P. merguiensis, P. vannamei

\section{INTRODUCTION}

White spot syndrome virus (WSSV) has devastated the penaeid shrimp industries since the early 1990s in the main producing countries in Asia and Latin America (APHIS, 1999; Crockford, 2001; O.I.E, 2003). After its discovery in 1992, this highly contagious disease has now been found to infect wild penaeid shrimp and other wild crustaceans (APHIS, 1999; Lightner, 1999). This disease clinically infects the penaeid shrimp although it may infect a wider range of crustaceans (Chang et al., 1998; Hossain et al., 2004; Kanchanaphum et al., 1998; Lo et al., 1996; Rajendran et al., 1999). Moreover, this disease has been experimentally and incidentally proven to cause mortality and severe infections among freshwater crustaceans (Corbel et al., 2001; Jiravanichpaisal et al., 2001; O.I.E, 2003). Furthermore, the present WSSV lineages are more virulent than their 96's ancestor, perhaps due

\# Corresponding author. Research Institute for Mariculture. Jl. Br. Gondol, Kec. Gerokgak, Kab. buleleng, Kotak Pos 140, Singaraja, BAli 81101 , Indonesia. Tel.: (0362) 92278, Fax. (0362) 92272/71 E-mail address: 
to their $16 \mathrm{~kb}$ smaller genome (Marks et al., 2005).

A white spot disease (WSD) outbreak in a shrimp farm is characterized by declining appetite and abnormal swimming on the water surface of affected shrimp (Corbel et al., 2001; Flegel, 1995). At later stages, some shrimps develop a red discoloration, die at the pond edges and at a more chronic phase, show white spots all over the body (Flegel, 1995). Histologically, shrimp will suffer massive apoptosis in all tissues including vital organs (Sahtout et al., 2001) and haemocytes (Hameed et al., in press). WSSV can be identified by PCR and in situ hybridization in the pleopods, gills, stomach, abdominal muscle, haemolymph, midgut, heart, pereiopods, lymphoid organs, integument, nervous tissue, hepatopancreas, testes, ovaries, spermatophores, and eye stalks (Lo et al., 1997). Clinically, WSSV-infected shrimp will be similar to environmentally-stressed animals by higher phenoloxydase (PO), lower prophenoloxidase (ProPO), lower total haemocyte counts (THC) (Sritunyalucksana et al., 1999), lower haemolymph protein level, lower clotting protein, and reduction in antioxidant enzymes (Mohankumar \& Ramasamy, 2006b; Yoganandhan et al., 2003). WSSV-infected shrimp will also exhibit significantly reduced activity of membrane-bound phosphatases in many tissues that lead to an increase in the production of free radicals and decreasing mitochondrial enzyme activity in infected tissues (Mohankumar \& Ramasamy, 2006a). Eventually the shrimps fail to coagulate their haemolymph which also occurs in TSV- infection (Song et al., 2003; Yoganandhan et al., 2003). At later stages of infection, viral particles can be found in any tissues of the shrimp (Rout et al., 2005) including in the haemocytes (Sahul Hameed et al., in press).

Finding early signs of mortality and abnormality has always been difficult in relatively large ponds. The farmers are usually aware of the problem at a very late stage and total mortalities most often occur 3 days after the initial discovery of some mortalities (Flegel, 1995). Some shrimps have red feces as a sign of eating rotten shrimp tissues. Healthy shrimp would prefer to eat recently dead shrimp (mostly appendages on cephalothorax) instead of the ration feed (Soto et al., 2001). These conditions are believed to instantly increase the total viral intake and trigger massive mortalities in the newly infected shrimps (Wu et al., 2001).
Studies of viral transmission among shrimps have been conducted by many authors via feeding infectious tissues (Wang et al., 1998; Soto et al., 2001), injection and immersion (Chou et al., 1998; Rajendran et al., 1999; Wu et al., 2001) and cohabitation with crabs (Rajendran et al., 1999). Studies of the effect of WSSV-transmission on shrimp were mostly carried out by oral route (Kanchanaphum et al., 1998), injections (Chang et al., 2003; Perez et al., 2005) or cohabitation. In the cohabitation experiment, the shrimp were positively infected by WSSV within 24 to 48 hours. In viral injected experiment, the mortality of shrimp at D-14 at low density reached $18 \%$ compared to $46 \%$ and $72 \%$ at higher densities. Removal of dead shrimp or physical separation may significantly reduce the cumulative mortalities (Rout et al., 2005). The study by Rout et al. (2005) concluded that transmission occurred horizontally via cannibalism and via waterborne route. It was found that the LD50s of two different WSSV injection preparations were estimated at 1:4.444 $\times 106$ and 1:4.505 $\times 106$ (Wu et al., 2001) while with immersion only $39 \%$ of the challenged shrimp died (Prior et al., 2003)

The cohabitation studies presumed that WWSV-naïve shrimp contracted the disease by digesting faecal materials or by exposure to free viral particles (Prior et al., 2003). As WSSV infects the haemocytes (Di Leonardo et al., 2005) and reduces the haemolymph clotting ability, small-free-infected haemocytes can easily be distributed in the water column and potentially infect shrimp or other crustaceans under cohabitation circumstances. There is little information on this possibility. These series of studies was carried out to determine the role of non-clotted-infected haemolymph as a possible viral transmission mechanism instead of cannibalism as previously known.

\section{MATERIALS AND METHODS}

\section{Experimental Animals}

WSSV-free penaeid shrimp were obtained from the Center of Brackishwater Aquaculture Development (CBAD) hatchery and controlled pond facilities in Jepara, Central Java, Indonesia. These experimental animals comprised batches of 24 banana shrimps (P. merguiensis) with $8 \mathrm{~g}$ mean bodyweight (BW), 24 white leg American shrimps (P. vannamei) $6 \mathrm{~g} \mathrm{BW}$, and 58 tiger shrimps (P. monodon), 15-18 g BW. All were confirmed to be WSSV-free by two step PCR 
prior to the experiment. All shrimps were selected in physically good condition based on the criteria of rough skin and firm bodies in moult stage $C$. These shrimps were reared in recirculation tanks for at least three days to adapt before being challenged with the virus. Sterile sea water used in this experiment was kept at salinity of $31 \mathrm{ppt}, \mathrm{pH} 8.1 \pm 0.6$, temperature $28.0 \pm 1.5^{\circ} \mathrm{C}$ and dissolved oxygen level at $5.2+1.7 \mathrm{ppm}$.

\section{Viral propagation}

WSSV was propagated from the fourth generation of local stock of severely infected tiger shrimp stored in a deep freezer $\left(-80^{\circ} \mathrm{C}\right)$. The new viral solution was extracted by slightly modified previous procedures (Corbel et al., 2001; Namikoshi et al., 2004). Briefly $3 \mathrm{~g}$ of gill tissue was chill-homogenized in $10 \mathrm{~mL}$ Leibowitz medium and after centrifugation at $3,000 \mathrm{G}$ for $10 \mathrm{~min}$ at $4^{\circ} \mathrm{C}$, the supernatant was filtered through a $0.22 \mu \mathrm{m}$ sterile membrane. The supernatant was then centrifuged at $10,000 \mathrm{G}$ for $20 \mathrm{~min}$ at $4^{\circ} \mathrm{C}$. The supernatant was then diluted 10 -fold with phosphate buffered saline PBS ( $\mathrm{pH}$ 7.4) for direct injection into the recipients at the rate of $0.05 \mathrm{~mL}$ per $10 \mathrm{~g}$ of shrimp.

All the five tiger shrimps receiving deep frozen WSSV-infected tissue homogenate and the ten shrimps at the subsequent injections showed a typical WSSV infection including inactivity, becoming moribund and rapid mortalities in less than 2 days.

\section{Haemolymph collection}

Donor tiger shrimps that received WSSV inoculation showed a declining appetite, moribund swimming, red discoloration and white spots on bodies. Non-clotting haemolymph $(\mathrm{NCH})$ was obtained from inactive red discoloration or white spotted shrimp. Each $20 \mathrm{~g}$ shrimp may produce 1.5-2.5 mL of grey-colored $\mathrm{NCH}$. After a two-minute clotting test, each individual NCH was stored in Eppendorf tubes, and then stored in a styrofoam box filled with ice flakes. A reconfirmation of non-clotting condition was performed on all haemolymph in tubes by gentle agitation. All NCH was mixed in one large sterile tube $(50 \mathrm{~mL})$ before it was divided into two smaller $(20 \mathrm{~mL})$ tubes. All tests and mixing were carried out under a biohazard hood.

\section{Injection and negative control experiment}

Two groups of twelve shrimps were injected with WSSV homogenate $(0.05 \mathrm{~mL} / 10 \mathrm{~g})$ from two separate viral stocks at the dorsolateral third abdominal inter segment. Another $12 \times 2$ shrimps were injected similarly with PBS solution (Wu et al., 2002). Commercial food was given at 3\% BW once per day but mostly was uneaten.

Eighteen negative control shrimps were reared in six separate stagnant water tanks fed with commercial feed (CP diet-3) 3\% BW three times a day. Three shrimps were taken each day and returned to other tanks after $0.04 \mathrm{~mL}$ of their haemolymph was withdrawn. These shrimps were then fed with 5 pieces of frozen anchovies per shrimp at first day of recovery until their haemolymph was retaken on the fifth day.

\section{Clotting time determination}

Haemolymph was drawn from the base of fourth pereiopod. Soon after ejection from the needle and timing started, haemolymph was stirred with the needle tip on a glass surface. All needles and syringes were used only once. If the haemolymph-clott diameter reached approximately 3-4 $\mathrm{mm}$ in size, the clotting time measurement ended. All times were recorded with a digital stop watch.

\section{$\mathrm{NCH}$ challenge and Controls}

The $\mathrm{NCH}$ challenges were conducted in the isolated wet lab of CBAD Station, Jepara Central Java. All facilities and procedures were run with the highest biosecurity possible. All three species of shrimp (24 each) were subdivided ( 12 for each species) into six $20 \mathrm{~L}$ water containers filled with $10 \mathrm{~L}$ sea water $(30 \mathrm{ppt}$, $28^{\circ} \mathrm{C}, 5.2 \mathrm{ppm} \mathrm{DO}$ ) with gentle aeration. The $\mathrm{NCH}$ was dropped with a $5 \mathrm{~mL}$ syringes simultaneously into the containers: $1.5 \mathrm{~mL}$ for each P. merguiensis and P. vannamei and $4.5 \mathrm{~mL}$ for P. monodon. Fifteen minutes after $\mathrm{NCH}$ immersion, all water and the shrimps were removed into separate larger $300 \mathrm{~L}$ fiberglass tanks with stagnant water system $\left(30 \mathrm{ppt}, 27^{\circ} \mathrm{C}-28^{\circ} \mathrm{C}\right)$ with gentle aeration to get the 4.8-5.1 ppm DO. Commercial feed was given at the rate of $3 \%$ of biomass three times a day.

A positive control experiment was carried out by feeding $12 \times 2$ tiger shrimps with 
Table 1. Summary of $\mathrm{NCH}$ experimental design

\begin{tabular}{|c|c|c|c|c|c|}
\hline Praw ns & & $\begin{array}{l}\text { Biomass } \\
\text { (g) }\end{array}$ & $\begin{array}{c}\text { NCH } \\
\text { Vol. }(\mathrm{mL})\end{array}$ & $\begin{array}{c}\mathrm{NCH}-p \text { raw n } \\
\text { ratio }(\mathrm{v} / \mathrm{v}) 1) \\
(\%)\end{array}$ & $\begin{array}{c}\mathrm{NCH}-\mathrm{w} \text { ater } \\
\text { ratio }(\mathrm{v} / \mathrm{v}) \\
\text { in } 300 \mathrm{~L} \\
\text { tanks }\end{array}$ \\
\hline P. merguiensis & (24) & 184 & 1.5 & $146.00 \%$ & $5 \mathrm{ppm}$ \\
\hline P. vannamei & (24) & 132 & 1.5 & $203.00 \%$ & $5 \mathrm{ppm}$ \\
\hline P. monodon & (24) & 390 & 4.5 & $206.00 \%$ & 15 ppm \\
\hline
\end{tabular}

1) healthy shrimp are assumed to have specific gravity 1.12

grounded whole infected shrimp tissue. The shrimps were starved for two ration feeding times before fed with the tissues at the rate of $20 \%$ of body weight (BW) per feeding, for two feeding times. The next feeding resumed with the commercial feed (CP diet 3 ) at the rate $3 \%$ BW three times a day.

The negative control was arranged similar to the positive control but fed with commercial feed only. Limited amount of new water was added into each tank daily (approximately 7\%-10\%). All waste and waste water from infected and non-infected tanks were collected in several $40 \mathrm{~L}$ water buckets, disinfected with calcium hypochlorite and drained into isolated septic tanks for further treatment.

Tools and facilities for all experiments were separated and treated with disinfectant (500 ppm Sodium hypochlorite) before and after use.

\section{Observation of clinical signs}

Three clinical factors were monitored during the $\mathrm{NCH}$ experiment: red discoloration (ReD), abnormal swimming (Abn), white spot development (WSp) and cumulative mortality (CM). The $\mathrm{NCH}$ immersion data were collected within 48 hours due to quick reactions while the feeding and control experiment were monitored for 8 days.

All clinical sign data were calculated in relative value (\%) to the current survivor at time of observation. Mortality data (CM) was arranged in cumulative total death at a designated time.

\section{Data analysis}

Log natural transformation was conducted for normal distribution of all data of $\mathrm{NCH}$-challenged study before further analysis. One way ANOVA analyses were applied for observation data by using statistical software SPSS version
12. Data were compared by the least significant difference (LSD) analysis and presented by mean \pm standard error. A significant level of 0.05 was set for all statistical analysis.

\section{RESULTS}

\section{Clotting time of normal shrimp}

All of the normal shrimps showed a similar clotting time. Statistically there was no significant effect between time in captivity (9 days) with the clotting time (one way ANOVA, $\mathrm{F}=0.16$, d. $f=2,29$ and $P>0.1$ ). The mean haemolymph clotting time under these conditions was 13.3 seconds (Figure 1.)

\section{Clotting time of WSSV-injected prawns and the controls}

After injection by WSSV homogenate, shrimps showed a longer clotting time compared to PBS injection and the negative control treatments (Figure 2A and 2B). All treatments had a significant effect for clotting time (one way ANOVA, $\mathrm{F}=59.06 \mathrm{~d} . \mathrm{f}=2,35$ and $\mathrm{P}<0.001$ ).

In the first two hours post-injection, the clotting time patterns were similar (Figure $2 \mathrm{~A}$.). At $8 \mathrm{hpi}$ and $16 \mathrm{hpi}$ shrimps received WSSV injection (WS inj) had significantly longer and non clotting haemolymph. Overall, injections had significantly longer mean clotting time than the other two controls (Figure 2B). Mean clotting time for WS-inj. was $98.42 \pm 17.45 \mathrm{sec}$ compared to PBS-inj. $(13.33 \pm 1.62) \mathrm{sec}$ and negative control $(9.92 \pm 0.72)$ sec with no significant difference between the last two.

\section{Non Clotting Haemolymph (NCH) challenges}

The $\mathrm{NCH}$ collected from heavily infected animal used in immersion tests showed that 


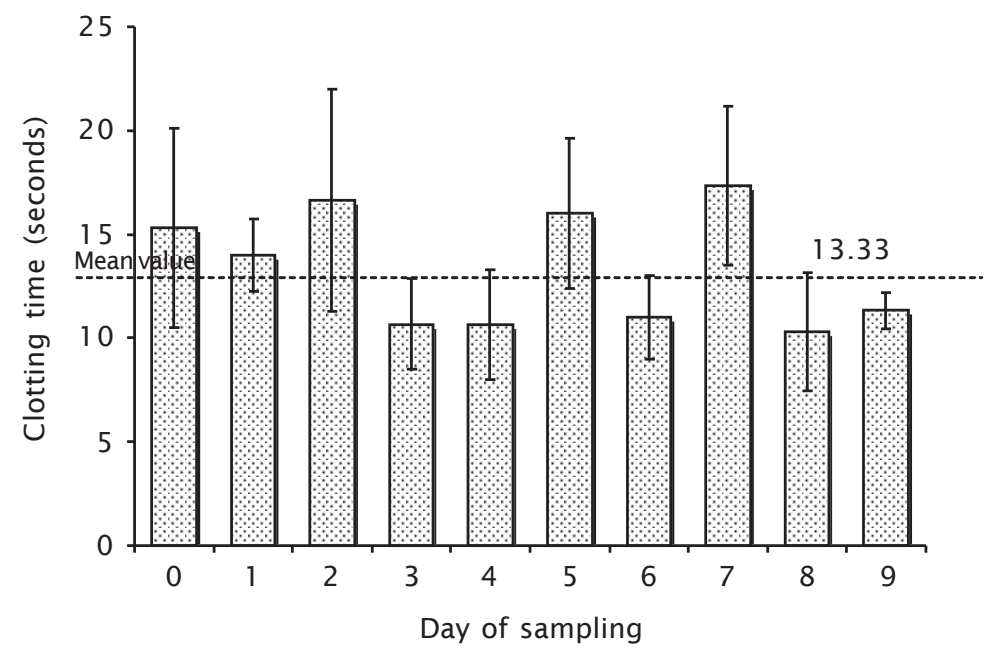

Figure 1. Daily haemolymph mean clotting time \pm standard error of three shrimp per sampling reared in five separate stagnant-water tanks. Haemolymph collection was repeated after five days

the infection was as severe as that of the injection treatment. The $\mathrm{NCH}$ challenge, compared with infected tissue feeding and the negative control, has a significant effect for most of the bioindicators measured.

The first clinical symptom observed, red discoloration (ReD), occurred on P. merguiensis did not get any color changes until 36 hours post exposure (hpe), which is statistically significant $(\mathrm{F}=3.76$ d. $\mathrm{f}=4,49$ and $\mathrm{P}<0.01)$ but most

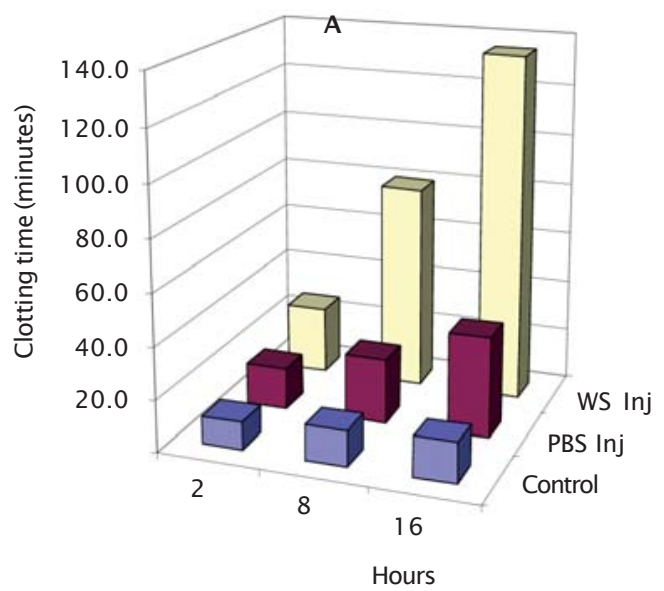

of the P. vannamei had shown this sign of infection 12 hpe. Meanwhile $P$. monodon immersed in $\mathrm{NCH}$ increased in ReD from 36 hpe to 96 hpe. Increasing ReD was also occurred in $P$. monodon fed with infected tissue from 48 hpe. The negative control showed little ReD (Figure $3 \mathrm{~A}$ ).

No white spots on the epicuticle were detected in either P. merguiensis or P. vannamei exposed to $\mathrm{NCH}$ (Figure $3 \mathrm{~B}$ ). However the P.

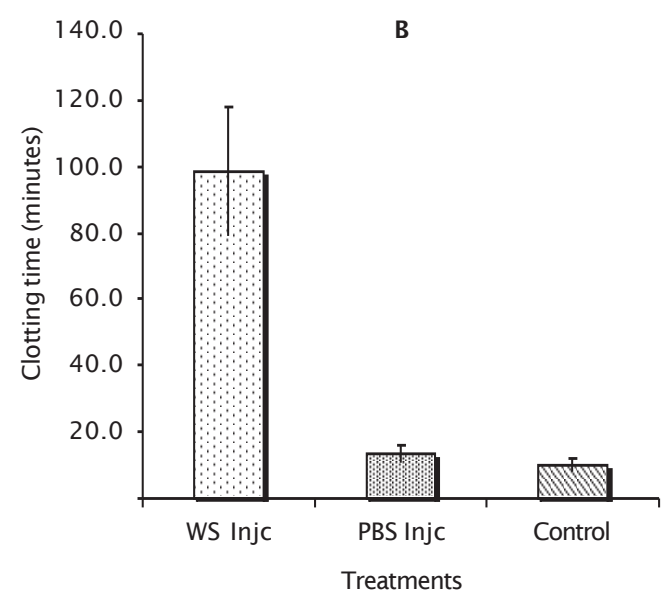

Figure 2. Clotting time on WSSV injected shrimps (WSinj) compared to those injected with PBS (PBS inj) and negative control (Control) in 2, 8 and 16 hpi (A) and differences among mean clotting time \pm standard error of each treatment $(P<0.05)(B)$ 
A

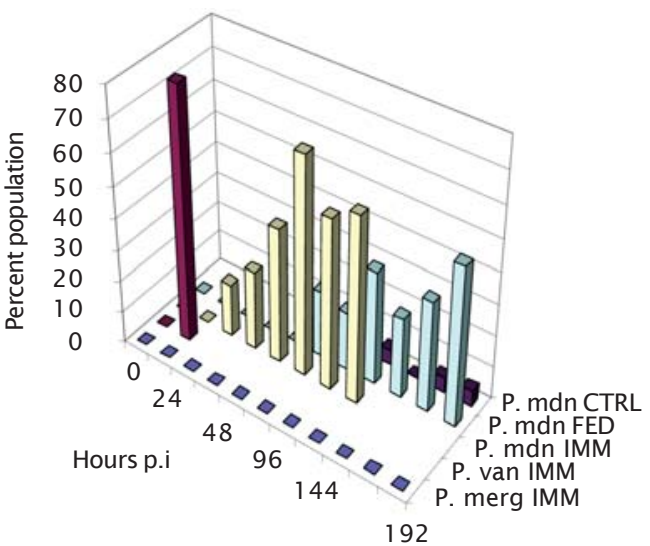

B

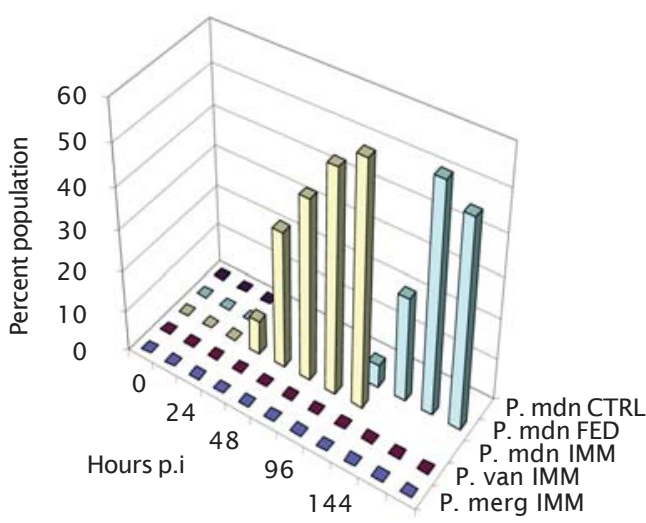

192

Figure 3. Percentage of surviving prawn populations challenged with different WSSV : $P$. merguiensis immersion (P merg IMM), P. vannamei immersion ( $\mathrm{P}$ van IMM), P. monodon immersion (P mdn IMM), P. monodon fed on infected tissue (P mdn FED), P. monodon negative control (P mdn CTRL) based on two clinical signs : Red discoloration (A) and White spots (B)

monodon immersed in $\mathrm{NCH}$ showed rapid development of white spots ( 1.5 days) compared to shrimp fed with infectious tissue (4 days) and none in the negative control $(F=3.427 \mathrm{~d} . \mathrm{f}$ $=4,49$ and $\mathrm{P}<0.05$ ).

Signs of cute infection (laying on side, moribund swimming, and curling pereiopods) were detected in all infection-challenged treatments and statistically significant $(F=4.584, d . f=4$, 49 and $P<0.005)$. In $P$. merguiensis and $P$. vannamei, the abnormality was first observed at $6 \mathrm{hpi}$ and reached its peak (100\%) at $18 \mathrm{hpi}$. While for P. vannamei the peak (75\%) was reached quicker at $12 \mathrm{hpi}$. In P. monodon, the infection of $\mathrm{NCH}$ progressed more slowly than the previous white prawns; it took $24 \mathrm{hpi}$ for the first sign of abnormalities and progressed until its peak at $120 \mathrm{hpi} \mathrm{(5} \mathrm{days).} \mathrm{In} \mathrm{the} \mathrm{fed-}$ challenged experiment the earliest sign of abnormalities was at $48 \mathrm{hpi}$ and slowly increased until it reached the peak at $192 \mathrm{hpi} \mathrm{(8}$ days).

$\mathrm{NCH}$ caused dramatic mortalities amongst tested shrimp $(\mathrm{F}=6.93$, d. $\mathrm{f}=4,49$ and $\mathrm{P}<0.001)$. $P$. merguiensis and $P$. vannamei all died within 18 hours (presented at $24 \mathrm{hpi}$ - on Figure 4B) while P. monodon all died at $120 \mathrm{hpi}$. P. monodon fed infected tissue reached $100 \%$ mortality in $192 \mathrm{hpi}$. The negative control shrimps showed no significant mortalities $(9.09 \%$ or 2 out of 22 shrimp) in 8 days (Figure 4B).

\section{Discussion}

The injection of WSSV homogenate in donor tiger shrimps had general clinical signs such as red discoloration, lost appetite and moribund swimming (abnormalities), white spots and rapid mortalities. The normal clotting time of 15 shrimps reared in fiber glass tanks to represent handling stress was 13.3 seconds.

Immersion with $\mathrm{NCH}$ at approximately $1.46 \%$ and $2.03 \%(\mathrm{~V} / \mathrm{v})$ for the P. merguiensis and P. vannamei and $2.06 \%$ for P. monodon may kill both shrimps in less than 2 days which was similar to injection in viral propagation steps in this study. The immersion at the first $15 \mathrm{~min}$ utes was equal to $150 \mathrm{ppm}$ to $450 \mathrm{ppm} \mathrm{NCH}$ in the $10 \mathrm{~L}$ of clean seawater and only 5 and 15 ppm onward. On the other hand, feeding infected tissue killed some of the shrimp after 6 days and totally killed the shrimps in 9 days (not accounted in 8 days-analysis).

The role of free virions or viral-loaded haemocytes in infecting living or apparently healthy shrimps is still poorly understood. By feeding infected tissues, shrimps will show clinical symptoms within 5 to 18 days (Wang et al., 1998). In this experiment, the clinical symptoms occur within 5 to 7 days. Variation in time may be due to different feeding practices, viral strains and the concentration of viral loads and handling stress. However, both of these 
A

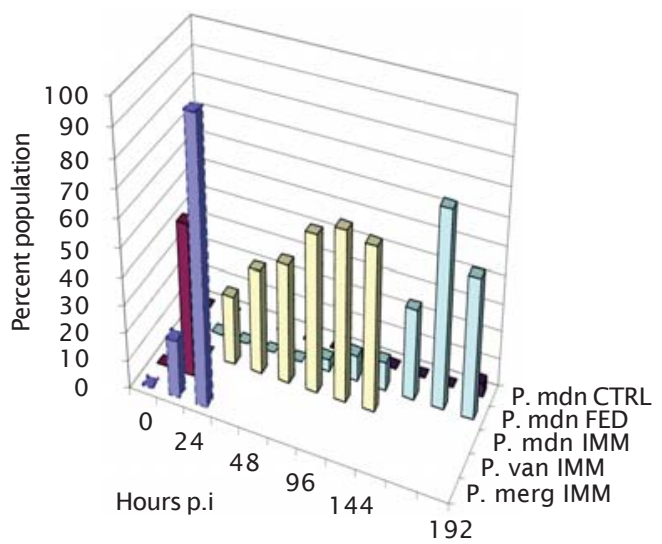

B

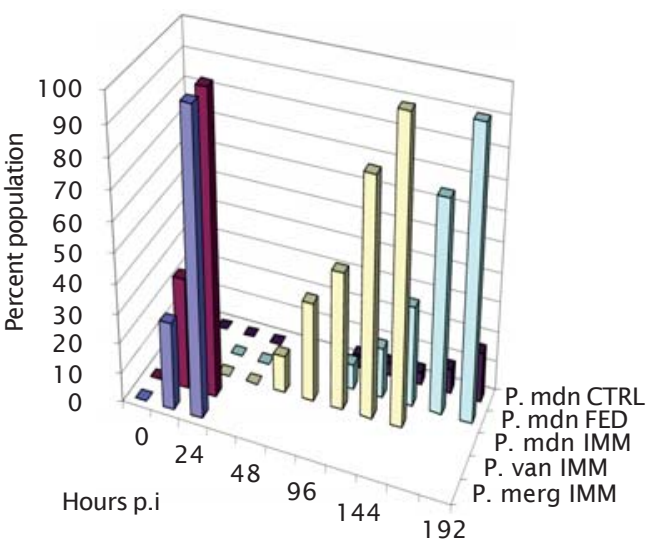

Figure 4. Percentage of surviving shrimp challenged with different WSSV : P. merguiensis immersion (P merg IMM), P. vannamei immersion (P van IMM), P. monodon immersion ( $P$ mdn IMM), $P$. monodon fed on infected tissue (P mdn FED) with $P$. monodon as negative control (P mdn CTRL) based on abnormalities (A) and cumulative mortalities (B)

explanations indicate that infection via ingestion of infected tissue did not induce disease as hypothesized for a WSD outbreak (3-4 days). During ingestion WSSV has to pass physical and chemical barriers before reaching the susceptible epithelial cells. Moreover the cuticle layers still protect any epithelial cells on the foregut while some protease, amylases and tripsin enzymes may form chemical barriers. Accordingly it is possible that the amount of WSSV may be significantly reduced (van de Braak, 2002). The foregut and hindgut constitute a very effective barrier against viruses essentially because of their structure: an inner layer of cuticle, then a digestive epithelium surrounded by a basal membrane tightly applied at the base of epithelial cells. The midgut possesses involve only the epithelial layer and the basal membrane (Escobedo-Bonilla et al., 2005). So at a very low level per os challenge on P. japonicus, the WSSV-positive nuclei could only be found in epithelial digestive cells (Okumura et al., 2004; Prior et al., 2003; Rajendran et al., 1999).

The clot formation is actually a physical mechanism to prevent the loss of body fluid and dissemination of foreign materials into haemocoel after an injury or infection ( $\mathrm{Di}$ Leonardo et al., 2005). Biologically, this mechanism was carried out by crosslink or protein polymerization of coagulogen (a clotting protein with a molecular mass of $340-400 \mathrm{kDa}$ ) (Soto et al., 2001), into clottable proteins (CP); this process is triggered by innate catalyses of a calcium dependent transglutaminase (TG)(Aono \& Mori, 1996; Martin et al., 1991; Okumura et al., 2004; Perazzolo et al., 2005) which is abundantly available in hyaline cells (Aono \& Mori, 1996; Perazzolo et al., 2005; Yeh et al., 1998). A series of studies on western rock lobster (Panulirus cygnus) revealed that after exercise or handling stress, total haemocyte counts (THC) will increase by increasing number of semi granulocyte cells but a decline in the number of hyalinocyte and granulocyte cells. These physically-stressed lobster showed a significant declining clotting time (Montano-Perez et al., 1999). But contrary to the above test, under WSSV infection, THC reduced drastically since most haemocytes (including the hyalinocytes) migrated to the infected tissues (Martin et al., 1991). Hyalinocytes, also known as explosive corpuscles dehisce, release their products to catalyze the coagulogen so loss of clotting is likely to be dependent on the decline of hyalinocytes (Chen et al., 2005).

The clotting mechanism relies on clotting proteins but under WSSV infection, protein profiles are drastically altered. Four new proteins and three intensely expressed high molecular weight proteins in haemolymph of infected shrimps were previously identified (Jussila et al., 2001). Furthermore WSSV infection creates higher glucose level and lower fatty acid in the haemolymph (van de Braak, 2002). The fail- 
ure of clotting formation under WSSV infection must involve one or all of the above factors.

The non-clotting haemolymph may contain free living virions (FLV) (Smith et al., 1995). In the haemolymph, these free viruses have been observed as enveloped virions and nucleocapsids associated with envelope debris (Rameshthangam \& Ramasamy, 2005). In contrast to the histology-based study by Yoganandhan et al. (2003) which stated that circulating haemocytes were not the target of WSSV infection, the $\mathrm{NCH}$ was found to contain the viral-loaded infected haemocytes (IH) especially at the granular and semi granular cells (Corbel et al., 2001; Okumura et al., 2005; van de Braak, 2002). These infectious materials are freely available in the water column for a certain time (Wang et al., 2002a). NCH probably released into the water from open cuts and wounds during cannibalism. In previous cohabitation studies, no information of any viral forms (FLV or IH) that had infected the healthy hosts (Wang et al., 2002b) and mostly using the virions homogenates from infected tissues in immersion studies.

The release mechanisms of FLV from unwounded hosts (Wang et al., 2002a) are still unknown and neither are the entrance mechanism into internal body system. The most likely exit is the hindgut via excretes and the entrance is the gill which is a relatively open organ. Gills, with their semi-permeable cuticle and mucosa layers, are highly vascularised. With its complex surfaces, the gill may trap some foreign particles including infected haemocytes.

The $\mathrm{NCH}$ volume $(1.5 \mathrm{~mL})$ required to kill $100 \%$ of P. merguiensis and P. vannamei was withdrawn from shrimps at the size of 15 grams. This NCH amount is analogous with two to three dead white shrimps or three dead tiger shrimps. In dying-shrimp-removal experiment (Anonymous) the shrimps took longer time to be infected in both removal and separation of dead shrimps, but after the current study, it is possible that separation of dead shrimps was actually preventing $\mathrm{NCH}$ leakage from an open cut during cannibalism. $\mathrm{NCH}$ is not exclusive to WSSV infection, it may also found in other pathogen's symptoms or shrimp under environmental and pollution stresses. This study has proven that $\mathrm{NCH}$ can be used as alternative way of WSSV survival strategy.

\section{CONCLUSION}

The cohabitation study on WSSV pathogenesis is likely more important for understanding the ultimate threat of this virus against cultivated and wild crustaceans. Infection from nonclotting haemolymph is similar to the induction of disease by injection in that it rapidly creates systemic infection. The feeding-infection route should take longer time. Quick and safe removal of dying shrimps from the pond edge before cannibalism is a critical point to prevent an outbreak. This study reveals the danger of $\mathrm{NCH}$ but the main question of the actual infective agents (FV or IH) and how to reduce the infectivity of these waterborne viruses are still unanswered. The next study should put more emphases on negative $\mathrm{NCH}$ traces after using well-filtered and aged water before and after being used in shrimp cultivation.

\section{ACKNOWLEDGMENT}

The authors would like to thank the ACIAR for funding travel and materials for this study under project FIS 2000/061. The help from staff of CBAD Jepara, Indonesia (Arif, Astuti, Evi, and Retno) with the provision of WSSV-infected specimens and the PCR testing, and Zaenal for providing space, tanks and field equipment, is much appreciated. Special thanks also given to Sardi and Siska who assisted us during preparation and sample collection, Mr. Darmawan and Mr. Kadek Ariawan who kindly provided WSSVfree shrimps used in this experiment. At last, the author would like to express his gratitude to Associate Professor Jesmond Sammut for reviewing the manuscript and the BRKP Indonesia for accepting this paper.

\section{REFERENCES}

Aono, H. \& Mori, K. 1996. Interaction between hemocytes and plasma is necessary for hemolymph coagulation in the spiny lobster, Panulirus japonicus. Comparative Biochemistry and Physiology Part A: Physiology, 113: 301-305.

APHIS, 1999. Outbreak of Shrimp Viral Disease in Central America: Situation Report , Veterinary Services. USDA National Aquaculture Program, Animal and Plant Health Inspection Service.

Chang, C.-F., Su, M.-S., Chen, H.-Y., \& Liao, I.-C. 2003. Dietary [beta]-1,3-glucan effectively 
improves immunity and survival of Penaeus monodon challenged with white spot syndrome virus. Fish and Shellfish Immunology, 15: 297-310.

Chang, P.-S., Chen, H.-C., \& Wang, Y.-C. 1998. Detection of white spot syndrome associated baculovirus in experimentally infected wild shrimp, crab and lobsters by in situ hybridization. Aquaculture, 164: 233242.

Chen, M.-Y., Hu, K.-Y., Huang, C.-C., \& Song, Y.L. 2005. More than one type of transglutaminase in invertebrates? A second type of transglutaminase is involved in shrimp coagulation. Developmental \& Comparative Immunology, 29: 1003-1016.

Chou, H.Y., Huang, C.Y., Lo, C.F. \& Kou, G.H., 1998. Studies on transmission of white spot syndrome associated baculovirus (WSBV) in Penaeus monodon and P. japonicus via waterborne contact and oral ingestion. Aquaculture, 164: 263-276.

Corbel, V., Zuprizal, Z., Shi, C., Huang, Sumartono, Arcier, J.-M., \& Bonami, J.-R. 2001. Experimental infection of European crustaceans with white spot syndrome virus (WSSV). Journal of Fish Diseases, 24: 377382.

Crockford, M. 2001. White Spot Disease. Australia and New Zealand Standard Diagnostic Procedures, 1.

Di Leonardo, V.A., Bonnichon, V., Roch, P., Parrinello, N., \& Bonami, J.-R. 2005. Comparative WSSV infection routes in the shrimp genera Marsupenaeus and Palaemon. Journal of Fish Diseases, 28: 565-569.

Escobedo-Bonilla, C.M., WilleAlday Sanz, V.M., Sorgeloos, P., Pensaert, M.B. \& Nauwynck, H.J. 2005. In vivo titration of white spot syndrome virus (WSSV) in specific pathogenfree Litopenaeus vannamei by intramuscular and oral routes, 66: 163-170.

Flegel, T.W. 1995. A turning point for sustainable aquaculture: the White spot virus crisis in Asian shrimp culture. Aquaculture Asia, 29-34.

Hossain, M.S., Otta, S.K., Chakraborty, A., Sanath Kumar, H., Karunasagar, I., \& Karunasagar, I. 2004. Detection of WSSV in cultured shrimps, captured brooders, shrimp postlarvae and water samples in Bangladesh by PCR using different primers. Aquaculture, 237: 59-71.

Jiravanichpaisal, P., Bangyeekhun, E., Soderhall, K., \& Soderhall, I. 2001. Experimental in- fection of white spot syndrome virus in freshwater crayfish Pacifastacus leniusculus. Dis. Aquat. Org., 47: 151-157.

Jussila, J., McBride, S., Jago, J., \& Evans, L.H. 2001. Hemolymph clotting time as an indicator of stress in western rock lobster (Panulirus cygnus George). Aquaculture, 199: 185193.

Kanchanaphum, P. Wongteerasupaya, C., Sitidilokratana, N., Boonsaeng, V., Panyim, S., Tassanakajon, A., Withyachumnarnkul, B. \& Flegel, T.W., 1998. Experimental transmission of White Spot Syndrome Virus (WSSV) from crabs to shrimp Penaeus monodon. Dis Aquat Org., 34: 1-7.

Lightner, D.V. 1999. The penaeid shrimp viruses TSV, IHHNV, WSSV, and YHV: current status in the Americas, available diagnostic methods and management strategies. J. Appl. Aquaculture, 9: 27-52.

Lo, C.-F., Ho, C.-H., Peng, S.-E., Chen, C.-H., Hsu, H.-C., Chiu, Y.-L., Chang, C.-F., Liu, K.-F., Su, M.-S., Wang, C.-H., \& Kou, G.-H. 1996. White spot syndrome baculovirus (WSBV) detected in cultured and captured shrimp, crabs and other arthropods. Disease of Aquatic Organisms, 27: 215-225.

Lo, C.F., Ho, C.H., Chen, C.H., Liu, K.F., Chiu, Y.L., Yeh, P.Y., Peng, S.E., Hsu, H.C., Liu, H.C., Chang, C.F., Su, M.S., Wang, C.H., \& Kou, G.H. 1997. Detection and tissue tropism of white spot syndrome baculovirus (WSBV) in captured brooders of Penaeus monodon with a special emphasis on reproductive organs. Dis Aquat Org., 30: 53-72.

Marks, H., van Duijse, J.J.A., Zuidema, D., van Hulten, M.C.W., \& Vlak, J.M. 2005. Fitness and virulence of an ancestral White Spot Syndrome Virus isolate from shrimp. Virus Research, 110: 9-20.

Martin, G.G., Omori, J.E.H.S., Chong, C., Hoodbhoy, T., \& McKrell, N. 1991. Localization and roles of coagulogen and transglutaminase in hemolymph coagulation in decapod crustaceans. Comparative Biochemistry and Physiology Part B: Biochemistry and Molecular Biology, 100: 517 522.

Mohankumar, K. \& Ramasamy, P. 2006a. Activities of membrane bound phosphatases, transaminases and mitochondrial enzymes in white spot syndrome virus infected tissues of Fenneropenaeus indicus. Virus Research, 118: 130-135.

Mohankumar, K. \& Ramasamy, P. 2006b. White 
spot syndrome virus infection decreases the activity of antioxidant enzymes in Fenneropenaeus indicus. Virus Research, 115: 69-75.

Montano-Perez, K., Yepiz-Plascencia, G., Higuera-Ciapara, I., \& Vargas-Albores, F. 1999. Purification and characterization of the clotting protein from the white shrimp Penaeus vannamei. Comparative Biochemistry and Physiology Part B: Biochemistry and Molecular Biology, 122: 381-387.

Namikoshi, A., Wu, J.L., Yamashita, T., Nishizawa, T., Nishioka, T., Arimoto, M., \& Muroga, K. 2004. Vaccination trials with Penaeus japonicus to induce resistance to white spot syndrome virus. Aquaculture, 229: 2535.

O.I.E, 2003. Manual of Diagnostic Tests for Aquatic Animals. Diseases of Crustaceans Listed by the OIE 4, Section 4.1.Chapter 4.1.2. White spot disease.

Okumura, T., Nagai, F., Yamamoto, S., Oomura, H., Inouye, K., Ito, M. \& Sawada, H. 2005. Detection of white spot syndrome virus (WSSV) from hemolymph of Penaeid shrimps Penaeus japonicus by reverse passive latex agglutination assay using high-density latex particles. Journal of Virological Methods, 124, 143-148.

Okumura, T., Nagai, F., Yamamoto, S., Yamano, K., Oseko, N., Inouye, K., Oomura, H., \& Sawada, H. 2004. Detection of white spot syndrome virus from stomach tissue homogenate of the kuruma shrimp (Penaeus japonicus) by reverse passive latex agglutination. Journal of Virological Methods, 119: 11-16.

Perazzolo, L.M., Lorenzini, D.M., Daffre, S. \& Barracco, M.A. 2005. Purification and partial characterization of the plasma clotting protein from the pink shrimp Farfantepenaeus paulensis. Comparative Biochemistry and Physiology Part B: Biochemistry and Molecular Biology, 142, 302307.

Perez, F., Volckaert, F.A.M., \& Calderon, J. 2005. Pathogenicity of white spot syndrome virus on postlarvae and juveniles of Penaeus (Litopenaeus) vannamei. Aquaculture, 250, 586-591.

Prior, S., Browdy, C.L., Shepard, E.F., Laramore, R. \& Parnell, P.G., 2003. Controlled bioassay systems for determination of lethal infective doses of tissue homogenates con- taining Taura syndrome or white spot syndrome virus. Dis. Aquat. Org., 54: 89-96.

Rajendran, K.V., Vijayan, K.K., Santiago, T.C., \& Krol, R.M. 1999. Experimental host range and histopathology of white spot syndrome virus (WSSV) infection in shrimp, prawns, crabs and lobsters from India. Journal of Fish Diseases, 22: 183-191.

Rameshthangam, P. \& Ramasamy, P. 2005. Protein expression in white spot syndrome virus infected Penaeus monodon fabricius. Virus Research, 110:133-141.

Rout, N., Citarasu, T., Ravindran, R., \& Murugan, V. 2005. Transcriptional and translational expression profile of a white spot syndrome viral (WSSV) gene in different organs of infected shrimp. Aquaculture, 245: 31 38.

Sahtout, A.H., Hassan, M.D., \& M., S. 2001. DNA fragmentation, an indicator of apoptosis, in cultured black tiger shrimp Penaeus monodon infected with white spot syndrome virus (WSSV). DAO, 44: 155-159.

Sahul Hameed, A.S., Sarathi, M., Sudhakaran, R., Balasubramanian, G., \& Syed Musthaq, S. Quantitative assessment of apoptotic hemocytes in white spot syndrome virus (WSSV)-infected penaeid shrimp, Penaeus monodon and Penaeus indicus, by flow cytometric analysis. Aquaculture In Press, Corrected Proof.

Smith, V.J., Swindlehurst, R.J., Johnston, P.A., \& Vethaak, A.D. 1995. Disturbance of host defence capability in the common shrimp, Crangon crangon, by exposure to harbour dredge spoils. Aquatic Toxicology, 32: 4358.

Song, Y.-L., Yu, C.-I., Lien, T.-W., Huang, C.-C., \& Lin, M.-N. 2003. Haemolymph parameters of Pacific white shrimp (Litopenaeus vannamei) infected with Taura syndrome virus. Fish and Shellfish Immunology, 14: 317-331.

Soto, A.M., Shervette, V.R., \& L., J.M. 2001 . Transmission of white spot syndrome virus (WSSV) to Litopenaeus vannamei from infected cephalothorax, abdomen, or whole shrimp cadaver. Dis. Aquat. Org., 45.

Sritunyalucksana, K., Sithisarn, P., Withayachumnarnkul, B., \& Flegel, T.W. 1999. Activation of prophenoloxidase, agglutinin and antibacterial activity in haemolymph of the black tiger prawn, Penaeus monodon, by immunostimulants. 
Fish and Shellfish Immunology, 9: 21-30. van de Braak, C.B.T., 2002. Haemocytic defence in black tiger shrimp (Penaeus monodon). PhD thesis, Wageningen University. ISBN 90-5808-651-8, 168 pp.

Wang, Y.C., Lo, C.F., Chang P.S. Wang, Y.C., Lo, C.F, Chang P.S., \& Kou G.H. 1998 Experimental infection of white spot baculovirus in some cultures and wild decapods in Taiwan. Aquaculture, 164: 221-230

Wang, Y.T., Liu, W., Seah, J.N., Lam, C.S., Xiang, J.H., Korzh, V., \& Kwang, J. 2002a. The white spot syndrome virus (WSSV) Infects specific hemocytes of the shrimp Penaeus merguiensis. (Abstract) in 5th Symposium on Diseases in Asian Aquaculture, Gold Coast, p. 168.

Wang, Y.T., Liu, W., Seah, J.N., Lam, C.S., Xiang, J.H., Korzh, V., \& Kwang, J. 2002b. White spot syndrome virus (WSSV) infects specific hemocytes of the shrimp Penaeus merguiensis. Dis. Aquat. Org., 52: 249-259.
Wu, J.L., Nishioka, T., Mori, K., Nishizawa, T., \& Muroga, K. 2002. A time-course study on the resistance of Penaeus japonicus induced by artificial infection with white spot syndrome virus. Fish and Shellfish Immunology, 13: 391-403.

Wu, J.L., Namikoshi, A., Nishizawa, T., Mushiake, K., Teruya, K., \& Muroga, K. 2001. Effects of shrimp density on transmission of penaeid acute viremia in Penaeus japonicus by cannibalism and the waterborne route. Dis. Aquat. Org., 47: 129-135.

Yeh, M.-S., Chen, Y.-L. \& Tsai, I.-H., 1998. The hemolymph clottable proteins of tiger shrimp, Penaeus monodon, and related species. Comparative Biochemistry and Physiology Part B: Biochemistry and Molecular Biology, 121: 169-176.

Yoganandhan, K., Thirupathi, S., \& Sahul Hameed, A.S. 2003. Biochemical, physiological and hematological changes in white spot syndrome virus-infected shrimp, Penaeus indicus. Aquaculture, 221:1-11. 